\title{
Walikan in the Linguistic Landscape of Malang: The Rise of a Local Youth Language
}

\author{
Nurenzia Yannuar* Yusnita Febrianti ${ }^{2}$ \\ ${ }^{1}$ Universitas Negeri Malang \\ ${ }^{2}$ Universitas Negeri Malang \\ *Corresponding author. Email: nurenzia.yannuar.fs@um.ac.id

\begin{abstract}
Walikan, spoken in Malang, Indonesia, is used among the youth to articulate a shared identity. This paper aims to investigate the role of Walikan in the linguistic landscape of Malang through semiotic modes analysis. Our data include Walikan signage in the city of Malang, mainly in the form of business signs, advertising boards, footballrelated banners, posters, landmarks, and graffiti. The analysis focuses on the text and images used in the signs. We study the content message and draw interpretation on two aspects: the motivation of why these messages are written in Walikan and the predicted impact on the recipients of the messages. The results of the study show that Indonesia's urban linguistic landscape does not have to be monolingual, it can also include local linguistic features. The paper also nudges on the use of the iconic blue colour, the colour of the city's football club, that is used in the signs. It is presumed that the iconic blue colour functions as a cohesive tie [1] and as the regional identity colour reflecting the pride of the local youths in Malang
\end{abstract}

Keywords: Walikan, public signs, colour, linguistic landscape, semiotic modes.

\section{INTRODUCTION}

This paper focuses on the linguistic landscape of Malang, East Java. A linguistic landscape allows us to analyse how languages are written and read in public spaces [2]. The presence of certain languages indicates social connections between public signs and the people [2]. For example, Shang and Guo [3] look into how shop owners in Singapore use language to communicate their connection to certain values and identities. Karam et al. [4] adopt a linguistic landscape to show the way Beirut has embraced a more modern identity by looking at the absence of Armenian and Arabic scripts in its streets. Sakhiyya and Martin-Anatias [5] use linguistic landscape as a tool that can give new life to local languages that are normally disregarded in the public domain. Our paper intends to investigate the role of Walikan, a youth language deriving from a local language, in this case, Javanese, in the linguistic landscape of Malang.

We seek to provide a better understanding of how Walikan interacts with other languages such as Javanese, Indonesian, and English in a multilingual environment. Yannuar [6] has shown the presence of Walikan in the public domain of Malang, in the form of banners, posters, newspaper columns, and business signs. In addition, Febrianti and Yannuar [7] describe how Walikan and Malangan Javanese are used in a nationally circulated movie.

The paper is divided into four sections. In Section 2 we introduce Walikan and its presence in the city. Section 3 explains semiotic modes and a visual grammar analysis framework used to analyse our data. Section 4 describes the data collection process and method. We then analyse the data by focusing on the text, image and colour used in the signs in Section 5. Our analysis focuses on the content message and we draw interpretation on two aspects: the motivation of why these messages are written in Walikan and the predicted impact on the recipients of the messages. The paper also looks at the use of the iconic blue colour, the colour of the city's football club, that is used in the signs.

\subsection{Walikan and its presence in the city}

The main characteristic of Walikan is word-reversal, a common feature in youth languages [8]; [9]. Walikan (literally means 'reversal') reverse words mainly from Malangan Javanese, a dialect of Javanese spoken in Malang, as well as words from Indonesian, Arabic, and English. The reversal follows total segment reversal, in 
this case, phonemes are reordered backwards (malay > yalam 'Malang'; pirs > srip 'how much'; makan > nakam 'to eat'). The words are then inserted into Malangan Javanese sentences. Speakers are free to use any number or word-reversal in their utterances, in which fluent speakers typically reverse all content words [6].

In the past, Walikan was used as an antilanguage among the city's criminals and street gangs, but today it is used as an emblematic language that can project a common identity [6]. Walikan was an oral practice when it was first developed in the 1940s, but since the last decade, it has been used in public spaces as a written practice [6].

Public signs in Indonesian city landscapes mainly use Indonesian, the national language of the country [10]; [11]); [6], however, observed that Walikan has been used in public spaces as a written practice. It is worth noting how Walikan, a youth variety of Malangan Javanese, can rise into public places for public audiences.

\subsection{Walikan and other semiotic modes}

The main focus in the study is the Walikan used in signs for various communicative purposes. In so doing, it accounts for the other semiotic modes found in the selected signs. It is commonly accepted that the current form of communication and representation of meanings does not only involve language, but also other semiotic modes such as images, colours, graphs, and in some formats, sounds. Unsworth and Chan [12] argue that images play a significant part in the meaning-making process. As images are increasingly used not only in a complementary role to the verbal texts but also as an independent means of conveying meanings, texts need to be analysed thoroughly based on the contributing semiotic modes.

The key framework of analyzing visual grammar is formulated by Kress and Van Leeuwen [13] in Reading Images: The Grammar of Visual Design. This framework provides a fundamental outline to understand the structure of meanings in various forms of texts containing predominantly visual or a combination of visual and verbal resources. Inspired by Systemic Functional theory (e.g., Halliday \& Hasan,[14]; Halliday \& Matthiessen, [15]; Martin, [16]; Martin \& Rose, [17]), Kress and Van Leeuwen's notion of visual grammar reflects the realization of a simultaneous threefold purpose in every text: represented content of the world, the relationship of the communicating interactants, and the relevant organization in the communication method [18]. Relevant to this study, it is observed that, other than language, the signs use images, fonts and colours as the combining semiotic modes to compose the overall signs.
Images are a type of semiotic mode [13]. They proposed an analogy that if the grammar of a language describes how the words combine in clauses, sentences and texts, then the 'visual grammar' describes how visualised elements such as people, places and things combine in visual 'statements' of greater or lesser complexity and extension (p. 1). Then, Van Leeuwen [13] proposed that written language presented as fonts or typography should be considered as a different semiotic mode due to its multimodal properties. He made the case for typography as a semiotic mode that is systematic, multimodal and can realise ideational, interpersonal and textual meanings via its distinctive typographic features such as its weight, expansion, slope, curvature, connectivity, orientation, and regularity. A more recent observation on semiotic mode is that of colour. Kress and Van Leeuwen [19] stated that the possibility of establishing colour as an independent semiotic mode is suggested because that colour is capable of realising systematic function. It can combine freely with many other modes, in architecture, typography, product design, document design, etc., but not exist on its own. However, it has a significant role when involved in a multimodal environment (p. 351).

Colour has meaning potential, but with greater metaphoric potential rather than specific meanings. This means potential will only be made specific in specific cultural and situational contexts [1]. Van Leeuwen [1] pointed out the role of colour in textual composition in which it contributes to making meaning concerning the specific functions of providing salience to elements that are considered particularly important, segmenting multimodal text into meaningful units by creating framings that are identified by different colours and providing cohesion. In this case, these roles of colour are seen in the variety of different multimodal text of signage as a unifying feature.

\section{METHODOLOGY}

Data used in this study were collected from 2015 , they are part of a corpus of Walikan. ${ }^{1}$ They include written Walikan in the form of printed texts on t-shirts, business signs, advertising boards, graffiti, pictures of landmarks and posters around the city's public spaces, as well as posters and banners created by the football supporters on the occasion of Arema Football Club anniversary in 2016. Additional data on signage were collected in 2021 to be used in this study.

The study is qualitative. Data in the form of .jpg files and .pdf documents were compiled. Afterwards, relevant samples for the study were selected for analysis. Selected data were categorised based on the types of communicative messages in the signs. Data

\footnotetext{
${ }^{1}$ They can be accessed through https://dataverse.nl/dataset.xhtml?persistentId=hdl:1041 1/TIGXZT.
} 
were then analysed based on the structure of Walikan used in the signage. Colour analysis was conducted at the final stage of data analysis to see the overall cohesion in the use of colour for the whole set of data.

\section{DISCUSSION}

The description of the data analyses is divided into two broad sections. First, our analysis focuses on the content message and we draw interpretation on two aspects: the motivation of why these messages are written in Walikan and the predicted impact on the recipients of the messages. Second, the study delves into the roles of colour as one of the important elements in the signage. The description is presented as follows.

\subsection{Walikan in the signage}

In this section, we describe the texts and interpret them to find out why they are written in Walikan and how they can affect the readers. The sample images of the signage are presented in Figures 1, 2, 3, and 4. In each Figure, the signage represents different functions. Figure 1 is signage used as a mural in a local neighbourhood. Figure 2 is also a mural painted on a wall. Figure 3 is three-dimensional signage, in which both Walikan and the featuring colour compose a landmark located in one main road of the city. Then, Figure 4 is graffiti sprayed onto a concrete wall.

Walikan is used in the signage to establish common ground, show local pride, and solidarity (see Yannuar [6] The examples of this communicative purpose are shown in Figure 1 and Figure 2, which are found as a mural in Kampung Tridi, Malang. The text written in Figure 1 is a Javanese phrase Aku wes tekan kene, umak kapan. Aku wes tekan kene 'I have arrived here' is a Javanese phrase. This phrase is often scribbled on the walls of various tourist attractions. Indonesian youth consider it as a way to mark their traces as they travel to different cool places.

Umak kapan (<kamu kapan) 'when is your turn' is a combination of a Walikan pronoun umak that is derived from the Indonesian word kamu ' $2 \mathrm{~s}$ ' and the Indonesian word kapan 'when'. Umak is an egalitarian singular second person pronoun used to express equal relationships among peers. Note that the only reversal in the phrase is umak, but it is already enough to indicate that the phrase is in Walikan, and is aimed at the Walikan community in the city. The phrase is meant to encourage the people of Malang to visit the same place and enjoy the ambience of the place.
Figure 1 Walikan signage as a mural (1)

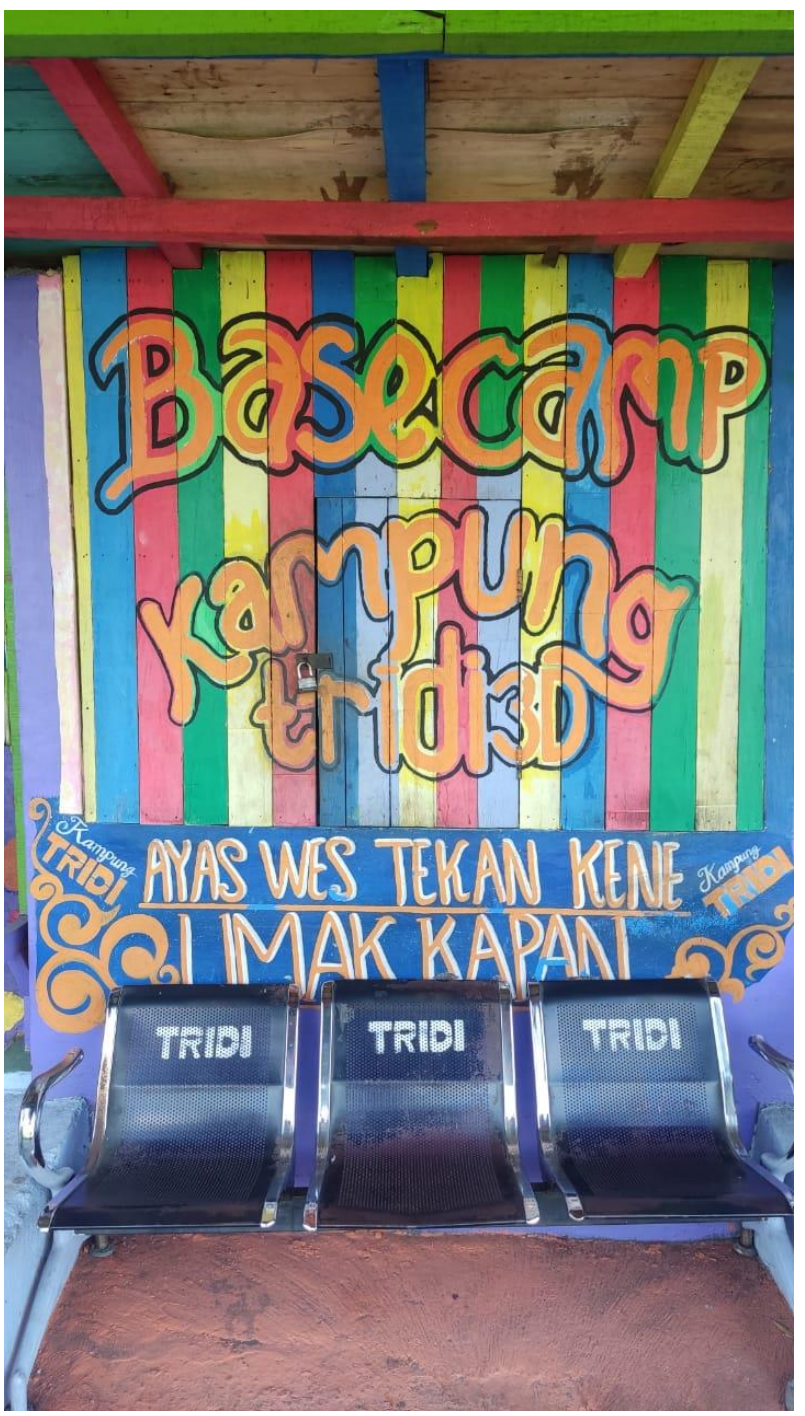

Figure 2 Walikan signage as a mural (2)

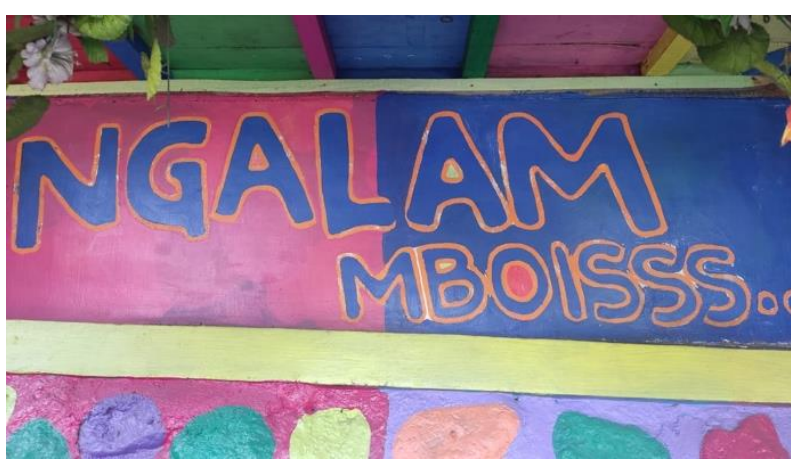

The text written in Figure 2 is Ngalam Mboisss.... Ngalam (<Malang) is a reversed word, denoting the name of the city. The expression Mboisss, on the other hand, means 'cool, trendy', which was borrowed from the English word boyish. The message underlines the pride of the people towards their city. 
Figure 3 Walikan signage as a landmark

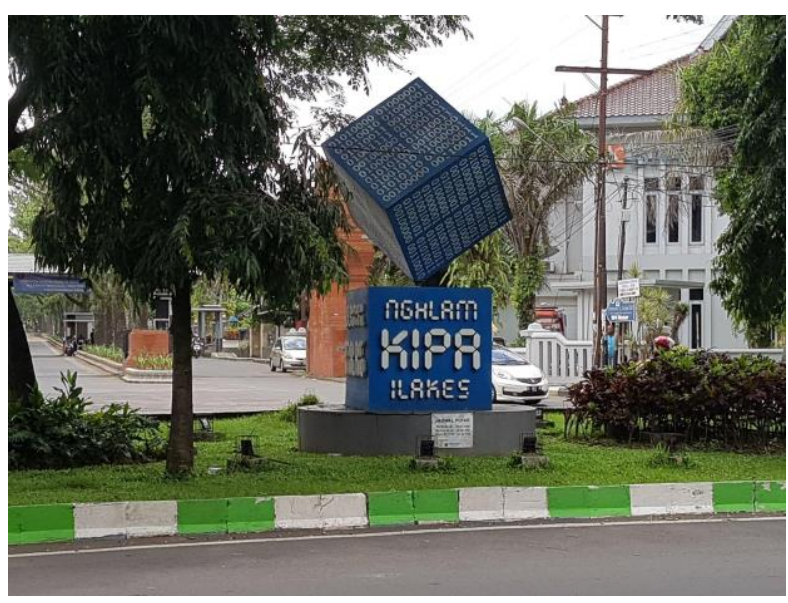

Figure 4 Walikan signage as graffiti

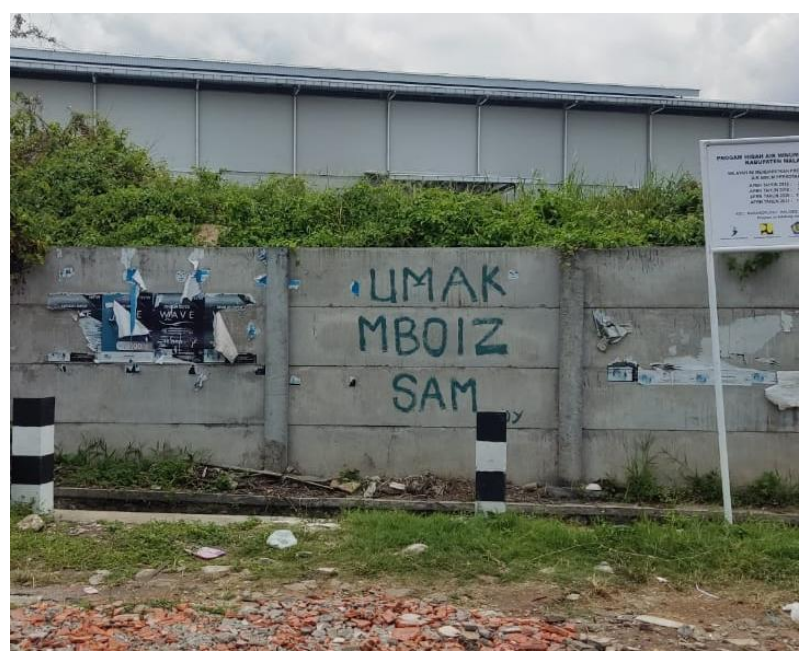

The writing on Figure 3 reads Ngalam kipa ilakes (< Malang apik sekali) 'Malang is very beautiful'. This phrase combines Javanese word apik (>kipa) 'good' and Indonesian word sekali (>ilakes) 'very'.

Our data collection also found an interesting example as shown in Figure 4. This graffiti, different from other examples, is presented plainly without many ornamental elements. The text reads Umak mbois sam ( $<$ Kamu mbois mas) 'You are cool bro'. It combines words from three languages, umak (<kamu) 'you' is from Indonesian, mbois is from English, while sam (<mas) is Javanese. The phrase is intended to be words of encouragement for the readers. Unlike the text in Figures 1 and 2, that of Figures 3 and 4 contains more word-reversal. It makes both signs noticeable to passersby.

The presence of Walikan is becoming more prominent. Most of the pictures in our corpus were collected in 2015 and 2016, and they are still in existence when we collect more data in 2021. During the Covid-19 pandemic, Walikan also appears in related posters and banners. It is used as a tool by local governments to help health-related messages directly reach the locals using a language that has more value for them.

\subsection{Colours in the signage}

The analysis of colour is focused on three aspects as suggested by Van Leeuwen [1], namely: (1) the role of colour to provide salience to important elements in the signage, (2) to segment the elements in the signage and (3) to provide cohesion. These aspects are discussed as follows.

In terms of contributing as a salient marker, a particular colour is combined with the contrasting colour to create the highlight. Figures 1 and 2 show murals presented in various colours. A focused examination of the typography, however, reveals that the salience of the written texts is contributed by the bright main colour and clear borderline at every letter that makes up the words. In Figure 1, all of the main written texts are using orange as the main colour. The black border at the top stack of the words and the white border at the bottom stack of the word clarify each of the letters. The main background between the top and bottom part are also distinctive. In Figure 2, the main written text is presented in blue with an orange border. The background divides the space vertically right in the mid-section of the overall area. Note that while they present the use of a combination of bright colours, blue features in both murals in the same hue.

Figure 3 shows the landmark found in one of the main streets in Malang. It only uses a combination of white and blue, with the emphasis on white as typography over the blue three-dimensional construction. This landmark seems to be very welldesigned to fit its purpose as a street sign on a busy main road. In contrast, Figure 4 shows a sign in graffiti with minimum aesthetical consideration. As it is found in one of the streets in Malang, however, it still serves as a sign to characterize the city. In addition to the use of Walikan, it also uses blue spray paint as a part of the city character.

In the samples, the signage is found in different contexts i.e., as a part of a mural, a formal landmark and a wall graffiti. Each of these places works as the space contextualization whereby they are found to serve their communicative purposes. The segmentation of the elements within the space of the signage does not hinder the presentation of the written text so that they are wellperceived by the passerby. The typography of the Walikan words in each of these signs freely floats on the signage space without borders. To some extent, this creates a blend of elements within the available space in the signage. It is important to note, however, that colour 
still performs its segmentation function by the clear arrangement of every element. For example, in Figures 1 and 2, amidst the various colours and the blue background, the letters are legible and clear to see for the passersby. This can be credited to the clear colour hues used in the signage. A similar concept is also clearly visible in Figure 3. Despite its simplicity, the written language in Figure 4 stands out due to the contrast of the blue spray paint and the cement background.

These samples are taken from three different locations in Malang. However, it can be noted that the colours used in this signage is showing a unifying character of blue. The use of blue is not a mere matter of aesthetic design choices. Two rationales can be drawn from the use of blue in these signages. First, based on colour analysis, it is clear that blue functions as a cohesive tie [1]. No matter where they were found, the signage is tied in themes by the colour of blue. Second, blue is a colour that has been used for Malang's local football club. Blue is the local identity of the people in Malang. To some extent, it may have equal importance to that of Walikan as a regional language identity of the local Malang people.

The overall implication from the use of both Walikan and the iconic blue reflects the regional identity of people in Malang. Both are the resources that are specific to the culture of people in Malang. It is unfortunate, however, that there are not enough grounds to say whether the use of these resources is well perceived by the people, or visitors, of Malang. It is certain, however, that the combination of Walikan and the iconic blue is the public display of the pride of the local youths in Malang.

\section{CONCLUSION}

Throughout the paper, we have shown that Walikan's presence in the linguistic landscape of Malang is a breath of fresh air for local and minor language positions in public spaces. Indonesian linguistic landscape is not only monolingual (Indonesian only), but it can also include local linguistic features. They can be used to establish common ground, show local pride, and create solidarity among locals and between the government and the local community.

By also looking at other semiotic modes in the signs such as colour, we found out that the blue colour in the signs functions as a cohesive tie. Perceived as the official colour of the local football club, blue symbolizes the regional identity of the Malang people. As a result, a combination of Walikan texts and blue colour amplifies the solidarity aspect between the signs and the people.

\section{ACKNOWLEDGMENTS}

We are grateful for the PNBP research funding given by the Faculty of Letters, Universitas Negeri Malang. We would also thank the other team members, Evynurul Laily Zen and Aulia Apriana. A special thanks are dedicated to our student, Muhammad Alhan Ananta Putra, who took additional Walikan pictures in 2021.

\section{REFERENCES}

[1] Van Leeuwen, T. (2006). Towards a semiotics of typography. Information Design Journal \& Document Design, 14(2), 139-155.

[2] Shohamy, E., \& Gorter, D. (Eds.). (2009). Linguistic landscape: Expanding the scenery. Routledge, Taylor \& Francis Group.

[3] Shang, G. \& Guo, L. (2017). Linguistic landscape in Singapore: what shop names reveal about Singapore's multilingualism. International Journal of Multilingualism, 14(2), 183-201.

[4] Karam, F. J., Warren A., Kibler, A. K., \& Shweiry, Z. (2018). Beiruti linguistic landscape: An analysis of private store fronts. International Journal of Multilingualism, 17(2), 196-214

[5] Sakhiyya, Z., \& Martin-Anatias, N. (2020). Reviving the language at risk: A social semiotic analysis of the linguistic landscape of three cities in Indonesia. International Journal of Multilingualism, 1-18.

[6] Yannuar, N. (2018). Wòlak-waliké jaman; Exploring contemporary Walikan in public space. Wacana, 19(1), 100-121.

[6] Yannuar, N. (2019). Bòsò Walikan Malangan: Structure and development of a Javanese reversed language [Doctoral Dissertation]. Leiden University.

[7] Febrianti, Y. \& Yannuar, N. (2022). The youth linguistic index: Narrative persuasion and sense of belonging in a movie trailer. In $\mathrm{C}$. Groff et al. (Eds.). Global perspectives on youth language practices. Mouton De Gruyter.

[8] Androutsopoulos, Jannis. (1998). Deutsche Jugendsprache. Untersuchungen zu ihren Strukturen und Funktionen. Frankfurt am Main: Peter Lang.

[9] Kießling, R., \& Mous, M. (2004). Urban youth languages in Africa. Anthropological Linguistics, 46(3), 303-341.

[10] Fakhiroh, Z., \& Rohmah, Z. (2018). Linguistic landscape in Sidoarjo City. NOBEL: Journal of Literature and Language Teaching, 9(2), 96-116. 
[11] Yannuar, N., \& Tabiati, S. E. (2016). Public signs in the city of Malang: A study on the linguistic landscape of Indonesia. In V. N. Santi, M. Huda, \& A. Himmah (Eds.), The changing face of language pedagogy: Exploring linguistics and literature (Vol. 1, pp. 119-134). UIN Maliki Press.

[12] Unsworth, L., \& Chan, E. (2009). Bridging multimodal literacies and national assessment programs in literacy. Australian Journal of Language and Literacy, 32(3), 245-257.

[13] Kress, G. \& Van Leeuwen, T. (2006). Reading images: The grammar of visual design. London: Routledge.

[14] Halliday, M. A. K., \& Hasan, R. (1986). Language, context and text: Aspects of language in a social semiotic perspective. Waurn Ponds, Vic: Deakin University Press.

[15] Halliday, M. A. K., \& Matthiessen, C. M. I. M. (2004). An introduction to functional grammar (3rd ed.). London: Arnold.

[16] Martin, J. R. (1992). English text: System and structure. Philadelphia: John Benjamins Pub. Co.

[17] Martin, J. R., \& Rose, D. (2007). Working with discourse: Meaning beyond the clause. London: Bloomsbury Publishing.

[18] Painter, C., Martin, J. R., \& Unsworth, L. (2013). Reading visual narratives: Image analysis of children's picture books. CT: Equinox Publishing.

[19] Kress, G. \& Van Leeuwen, T. (2002). Colour as a semiotic mode: Notes for a grammar of colour. Visual Communication, 1(3), 343-68. 